\title{
Impact assessment of treating wastewater on the physiochemical variables of environment: a case of Kermanshah wastewater treatment plant in Iran
}

\author{
Siamak Baharvand ${ }^{1 *}$ and Mohammad Reza Mansouri Daneshvar²]
}

\begin{abstract}
Background: The most critical step to control sewage pollution and recycle of wastewater is to establish sewage treatment plants and to monitor their performance. This research aims to assess the environmental impacts of effluent waters, treated by Kermanshah wastewater treatment plant (KWTP), on some physicochemical variables of the adjacent river named as Qarasou River, northwestern Iran. Several water samples were collected from different locations into KWTP and along the Qarasou River in different time intervals of April and July 2017 to assess the effect of treated waters on the environment water quality. As well, an integrated environmental change index $\left(\Delta Y_{j}\right)$ was defined to assess the degree of changes and impacts in the current status.

Results: The analyses indicated that the values of total suspended solids (TSS), nitrate $\left(\mathrm{NO}_{3}\right)$, phosphorous (P), biological oxygen demand (BOD), and chemical oxygen demand (COD) overall decreased by treatment process at effluent water compared with raw sewage amounts. Contrarily, amounts of acidity and dissolved oxygen (DO) slightly increased in effluent water due to the aeration processes during the treatment process. The environmental change index $\left(\Delta Y_{j}\right)$ was estimated between 0.04 and 0.88 with an average of 0.28 for all variables in different time intervals, indicating the lowest degree of environmental changes and higher efficiency of treating wastewater in KWTP.
\end{abstract}

Conclusions: The results concluded the efficiency for the removal TSS, $\mathrm{NO}_{3}, \mathrm{BOD}$, and $\mathrm{COD}$ is estimated $80-92 \%$ during the water purification process in KWTP as an acceptable efficiency. Finally, it can be mentioned that the activated sludge process of KWTP has not any risky impacts on Qarasou River and the whole environment.

Keywords: Urban sewage, Treatment plant, Physicochemical variables, Kermanshah wastewater treatment plant (KWTP)

\section{Introduction}

Wastewater can be produced by more than $80 \%$ of the total consumed water in urbanized areas (Metcalf 2003). Reuse of treated wastewater constitutes a perfect alternative in many cases such as surface water and groundwater recharge. Consideration of treated wastewater, as a valuable source of recycling water for various consumptions,

\footnotetext{
*Correspondence: s.baharvand@khoiau.ac.ir

1 Department of Geology, Basic Science Faculty, Islamic Azad University of Khorramabad, Khorramabad, Iran

Full list of author information is available at the end of the article
}

is one of the most important goals of establishing wastewater treatment plants (WTPs) especially in arid regions (Tchobanoglus et al. 2003; Tyagi et al. 2008).

Nowadays, the wastewater treatment plant gives rise to an environmental impact due to its energy reserve, chemical compounds, and emissions to the atmosphere and sludge production (Hospido et al. 2004). For instance, discharging of the mentioned large volume of effluents waters to receiving sources and the surrounding environment has been produced a destructive environmental impact (Kobya et al. 2006). 
Several approaches are considered to assess surface water quality. In the conventional environmental assessment, the legislators consider the pollution in the outlet of all pollutant sources using fieldwork operations. However, using environment-based standards, some qualitative measurement is carried out at a specific point in the aquatic environment (Boyd and Greenwood 2005). The measurements of urban sewage are depended on water quality modeling of chemical, physical, and biological properties (Zhang et al. 2012). Hence, responsible organizations for the environment and health worldwide have developed guidance and standards for this purpose.

Purification and treatment of urban wastewater is an essential part of water resource management because it is possible to recycle treated water for increasing human consumption. Discharge of urban wastewater containing harmful chemicals to the environment is considered as a main environmental problem issue in developing countries such as Iran. In recent decades, the increasing growth of urbanization of Iran has led to entry the high amounts of sewage into the aquatic environment.

The pollution of water resources by wastewater discharge is categorized as a severe threat to human societies and the natural environment (APHA 1992). For instance, Essien (2010) has investigated the sewage pollution load of nitrates in a river in Nigeria. Deng et al. (2010) have studied the total pollution load of phosphates and COD in a river in China. Accordingly, the selection of the proper purification methods is depended on the main pollution loads and sensitivity of the environmental resources in each region.

This research aims to study the environmental effects of Kermanshah wastewater treatment plant (KWTP) on the adjacent river named as Qarasou River. In previous papers, researchers have studied the treatment process of some treatment plants of Kermanshah province in order to determine parasite presence in raw sewage (e.g., Sharafi et al. 2015a, b, Almasi et al. 2016, Dindarlou and Dastourani 2017). Sharafi et al. (2015a, b) have estimated the measurement of the presence of the biological parasite in treated and raw sewage of KWTP, encouraging its proper disinfection method. Almasi et al. (2016) have investigated the economic cost and efficiency of KWTP, indicating the economic efficiency of its treatment process. Furthermore, Dindarlou and Dastourani (2017) have reported the proper effectiveness of KWTP's treated water for reuse in agricultural irrigation.

Despite literature as mentioned above, the direct/indirect effects of KWTP on natural water resource have not been considered to more assessment. Hence, the main novelty of this study is depended on a general attitude to assess the spatial/temporal variations of KWTP's treated/untreated wastewater on the adjacent river. For this purpose, several water samples are collected from different locations into KWTP and along the Qarasou River in different time intervals of April and July 2017 to investigate the effluent effect of the treatment plant on water quality. Furthermore, an integrated environmental change index $\left(\Delta Y_{i}\right)$ is defined to assess the degree of changes and impacts in the current status.

\section{Study area}

In the present paper, Kermanshah wastewater treatment plant (KWTP) is considered as the study area with a surface area of about $120 \mathrm{Ha}$, which is located in southeastern Kermanshah city with geographical coordinates of $34^{\circ} 18^{\prime} 20^{\prime \prime}$ Northern latitude and $47^{\circ} 08^{\prime} 55^{\prime \prime}$ Eastern longitude (Fig. 1). In hydrological divisions, this region belongs to Kermanshah plain from Great Karkheh basin (northwestern Iran).

The KWTP is the main treatment center that collects urban sewage by piping lines and effluents treated waters using a channel into adjacent Qarasou River, as the main drain stream of Kermanshah plain. Topographically, KWTP is located in elevation height of $1310 \mathrm{~m}$ above sea level (a.s.l). Geologically, the most land units of the region are alluvial sedimentations with calcareous soil horizons depended on great carbonated formations of Zagros mountainous zone (GSI 2015). Furthermore, the study area has a semi-arid climate with a mean annual temperature of $14{ }^{\circ} \mathrm{C}$ and annual precipitation of $400 \mathrm{~mm}$ (Hijmans et al. 2005).

\section{Data and methods}

Data collection

In hydrological researches, the qualitative criteria are investigated together with the quantitative study of water budgets. A qualitative survey mainly is focused on contamination components of surface and groundwater. In this study based on several well-known methods (e.g., Singh et al. 2004; Farzadkia et al. 2016) several water samples were collected from different locations into KWTP and along the Qarasou River in different time intervals of April and July 2017 to investigate the effluent effect of the treatment plant on water quality. In this regard, nine physiochemical variables are considered including total suspended solids (TSS), water temperature, alkalinity, acidity $(\mathrm{pH})$, nitrate $\left(\mathrm{NO}_{3}\right)$, phosphorus $(\mathrm{P})$, biochemical oxygen demand (BOD), chemical oxygen demand (COD), and dissolved oxygen (DO). The mentioned variables are considered into five locations at the entrance of raw sewage into the treatment plant, at the aeration basin, at the effluent treated water, at the upstream, and at the downstream of KWTP along the Qarasou River, respectively.

All of the abovementioned variables were determined based on previous studies in this field (Manjunath et al. 


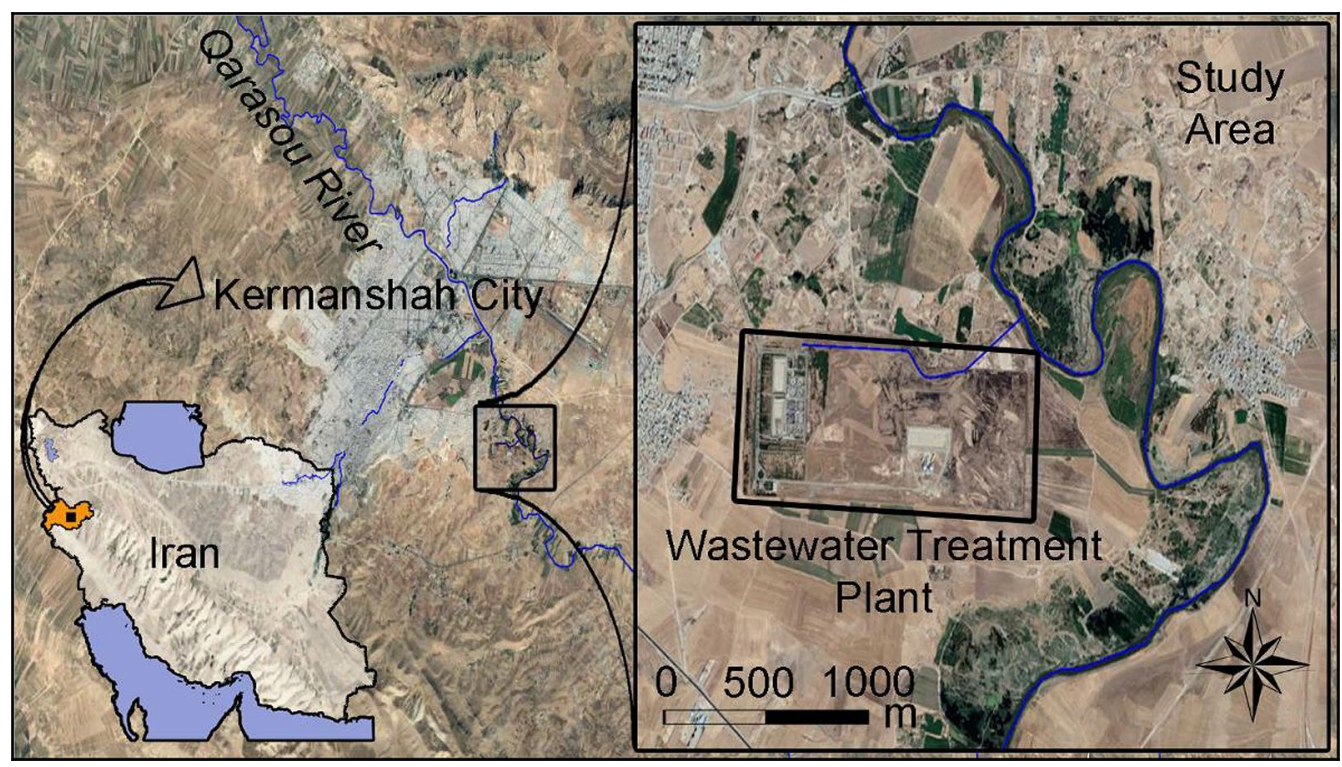

Fig. 1 General place and site of the wastewater treatment plant

2000; Caixeta et al. 2002; Del Pozo and Diez 2005) and all of them were measured in duplicates according to standard methods for the examination of water and wastewater (APHA 1992). The results of variables were compared to the standards of pollutants in effluent treated waters (Table 1) produced by the Environmental Protection Organization of Iran (EPO 2015). The EPO is a responsible agency in the field of water pollution control, preparation of the environmental protection policy and the laws, directives, and systems necessary for evaluating the impacts.

\section{Process of KWTP}

The primary process of wastewater treatment in the study area for a range of 800,000 populations is based on the activated sludge process (Fig. 2). According to this process, urban sewage is collected using pipelines into the plant. Then, several stages are carried out on collected sewage in order to produce treated water by 0.5 million $\mathrm{m}^{3} /$ day. After transferring the sewage to the treatment center, the screening stage starts to remove solid wastes using drum filters. In the next stage, the wastewater is conducted to aeration basins in order to start an aero-biologic process of sludge removal. Into filtration stage, the sewage is compressed using membrane micro-filters to remove solid sludge. In sedimentation basins, precipitated biochemical liquid sludge is eliminated from treated water. Finally after simple disinfection, the treated water effluents arrive at Qarasou River using an auxiliary channel. Researchers have reported
Table 1 Standards of pollutants in effluent treated waters based on EPO (2015)

\begin{tabular}{lllll}
\hline No. & Variable & $\begin{array}{l}\text { Effluent } \\
\text { to surface } \\
\text { water }\end{array}$ & $\begin{array}{l}\text { Effluent } \\
\text { to groundwater }\end{array}$ & $\begin{array}{l}\text { Use } \\
\text { in agriculture } \\
\text { and irrigation }\end{array}$ \\
\hline 1 & $\mathrm{TSS}(\mathrm{mg} / \mathrm{l})$ & 40 & - & - \\
2 & Temp. $\left({ }^{\circ} \mathrm{C}\right)$ & - & - & - \\
3 & Alkal. $(\mathrm{ppm})$ & - & - & - \\
4 & $\mathrm{pH}$ & $6.5-8.5$ & $5-9$ & $6-8.5$ \\
5 & $\mathrm{NO}_{3}(\mathrm{mg} / \mathrm{l})$ & 50 & 10 & - \\
6 & $\mathrm{P}(\mathrm{mg} / \mathrm{l})$ & 6 & 6 & - \\
7 & $\mathrm{BOD}(\mathrm{mg} / \mathrm{l})$ & 30 & 30 & 100 \\
8 & $\mathrm{COD}(\mathrm{mg} / \mathrm{l})$ & 60 & 60 & 100 \\
9 & $\mathrm{DO}(\mathrm{mg} / \mathrm{l})$ & 2 & - & 2 \\
\hline
\end{tabular}

the similarly activated sludge in the treatment process with high removal efficiency (Mannino et al. 2008).

\section{Environmental change index}

In this study, an integrated characteristic is defined named as change index $(C)$. Changes in response to perturbations can be evaluated as local environmental sensitivity (Burdon et al. 2016). According to Burdon et al. (2016), the change index can be applied to assess local sensitivity and environmental changes in response to an anthropogenic disturbance (i.e., pollution by treated wastewater) as below equation:

$$
\Delta Y_{i}=\frac{Y_{i}}{X} \times \Delta X
$$




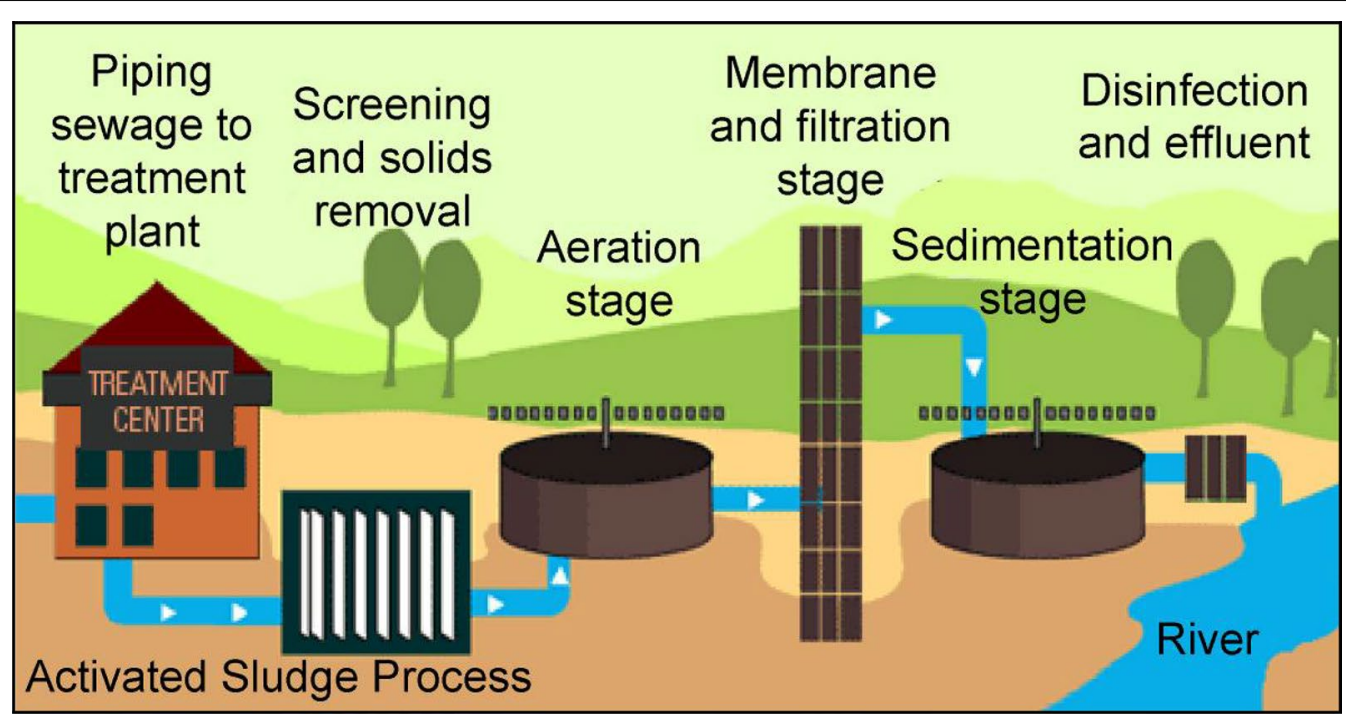

Fig. 2 Schematic process of the wastewater treatment plant

where $Y_{i}$ is an existing metric of an environmental variable at $i$ (i.e., a point in time or space), $X$ is a current level of pollution, and $\Delta Y_{i}$ is an index of environmental change depending on the pollution modification ratio $\Delta X$.

In the present study, $\Delta X$ is a ratio of the division of the variable values at the effluent water by the raw sewage. $Y_{i}$ is the mean variable value at the upstream, and downstream. Therefore, $X$ is the current variable value at the downstream. By quantifying the characteristics as mentioned above, the change of environmental status affected by treating process is estimated.

The minimum value of $\Delta X$ (close to zero) depends on the high efficiency of the treating process, revealing the lesser value of the pollution at the effluent water against the raw sewage. Contrarily, the maximum value of $\Delta X$ (close to one) reveals that the pollution value at effluent water is close to raw sewage. Likewise, the minimum value of $\Delta Y_{i}$ (close to zero) relates to the lesser degree of changes and impacts in the environment, while the maximum value of $\Delta Y_{i}$ (close to one) reveals the higher degree of changes and impacts in the environment.

\section{Results and discussion}

\section{Environmental setting}

Qarasou River with the major trend of NW-SE and a length of $200 \mathrm{~km}$ is the main drain stream of Kermanshah plain. The river is raised from Ravansar region (with distance $50 \mathrm{~km}$ ) in northern elevations of Kermanshah province (with mean height of 1600 a.s.l.), is flowed among Kermanshah city, is passed from eastward of KWTP and finally is joined to Gamasiab River in southern reliefs (with mean height of 600 a.s.l.).
Qarasou River as the main drain stream of Kermanshah plain (with a total area of $700 \mathrm{~km}^{2}$ ) has a crucial role in the preparation of water supply for agriculture and the urban assumption by annual discharge approximately to 150 million $\mathrm{m}^{3}$. This water discharge of the plain is contributed to about $16 \%$ and $8 \%$ of the total discharge of Kermanshah province and Great Karkheh basin, respectively.

\section{Investigation of physiochemical variables Total suspended solids (TSS)}

Solid suspended particles in water may be composed of organic or inorganic particles or incompatible fluids. Urban sewage usually has massive amounts of suspended solids, which are mostly organic incompatible fluids, such as oils and greases, are considered as sewage ingredients. Industrial water consumption may lead to organic or mineral impurities introduction into water. Suspended solids prepare chemical and biological substances adsorption. Biologically, suspended solids are included pathogenic microorganisms, such as organisms that are toxin producer in algae chains. The amount of all solids suspended or dissolved in water (organic or inorganic) are measured to obtain TSS. This measurement is determined by the evaporating the sample to the dry phase and measuring the residual mass. The total amount of the remaining mass is expressed in $\mathrm{mg} / \mathrm{l}$. A drying temperature, slightly higher than the boiling point $\left(104{ }^{\circ} \mathrm{C}\right)$, is adequate to remove liquid as well as absorbed water at the solid particle surface. Most solid suspended solids can be separated from water by filtration so the suspended solids in a water sample can be estimated by 
water filtering, drying the remaining mass, and filtering to a constant weight at a temperature of $104{ }^{\circ} \mathrm{C}$ and determining the remaining mass on the filter.

After drying and measuring the samples, the amount of organic matter of suspended solids and total solids can be obtained by igniting the residual masses at $600{ }^{\circ} \mathrm{C}$ in $1 \mathrm{~h}$. The organic part of the residual mass will be converted into carbon dioxide, vapor, and other gases, released to the environment. When the organic matter of suspended solids is measured, it is necessary to use a filter, made of fiberglass or some other resistant material, which does not decompose against high temperatures. The suspended solid variable is used to measure the quality of purification processes and the effluent flow. The Environmental Protection Organization of Iran (EPO 2015) has set a threshold for most of the suspended solids as $40 \mathrm{mg} / \mathrm{l}$ in treated waters. The results of this variable measurement are shown in Table 2 and Fig. 3a. On this basis, the TSS value has been overall decreased by treatment process at effluent water $(20-25 \mathrm{mg} / \mathrm{l})$ compared with raw sewage amounts (110-140 mg/l). In April time interval, the variable values are estimated lesser than July due to dryness and evaporate effects increase TSS values in July into both raw sewage and treatment process.

Furthermore, TSS value in the effluent water is in similar range or lesser than water samples in upstream and downstream. The TSS in all samples is lesser than the environmental standard of EPO $(<40 \mathrm{mg} / \mathrm{l})$. Therefore, the removal efficiency for the TSS is estimated equal
81-82\% during the water purification process in KWTP (Table 3 and Fig. 4).

\section{Water temperature}

Temperature affects the chemical reactions that occur in natural water systems. Furthermore, there is a significant relationship between temperature and gases solubility in water. The water temperature depends on many factors, such as atmospheric temperature. Shallow water reserves are more affected by atmospheric temperature than deeper water reserves. Cold waters usually have a wider variety of biological species. At lower temperature, bioactivity is at the lower rate.

For bacterial activity, the optimum temperature is in the range of 25 to $35^{\circ} \mathrm{C}$ (Metcalf 2003). The abundance of algae is commonly found in warm waters. Larger species of living organisms in water, such as fishes, are controlled by the temperature and the amount of oxygen dissolved in water. Changes in temperature affect the speed of chemical reactions and chemicals solubility. Most chemical reactions, such as the solution of solids, are faster due to increased temperatures.

On the other hand, gas solubility is reduced in the higher temperature, because the biological oxidation of organic substances in water depends on the high amount of dissolved oxygen. Measuring the water temperature of samples revealed similar values for treated and natural water temperature at different times $\left(22-23{ }^{\circ} \mathrm{C}\right.$ on July and $17-18{ }^{\circ} \mathrm{C}$ on Apr). Hence, the KWTP has not any change in this variable (Table 2 and Fig. $3 b$ ).

Table 2 Physicochemical variables based on spatial and temporal sampling

\begin{tabular}{|c|c|c|c|c|c|c|c|}
\hline No. & Variable & Time & Raw sewage & Aeration basin & Effluent water & Upstream & Downstream \\
\hline \multirow[t]{2}{*}{1} & TSS (mg/l) & April & 110 & 15 & 20 & 10 & 20 \\
\hline & & July & 140 & 100 & 25 & 100 & 30 \\
\hline \multirow[t]{2}{*}{2} & Temp. $\left({ }^{\circ} \mathrm{C}\right)$ & April & 18 & 17 & 18 & 17 & 18 \\
\hline & & July & 23 & 22 & 23 & 22 & 23 \\
\hline \multirow[t]{2}{*}{3} & Alkal. (ppm) & April & 390 & 300 & 310 & & \\
\hline & & July & 380 & 370 & 350 & & \\
\hline \multirow[t]{2}{*}{4} & $\mathrm{pH}$ & April & 7.9 & 7.7 & 7.6 & & \\
\hline & & July & 7.8 & 7.5 & 7.5 & & \\
\hline \multirow[t]{2}{*}{5} & $\mathrm{NO}_{3}(\mathrm{mg} / \mathrm{l})$ & April & 10 & 8 & 10 & 6 & 8 \\
\hline & & July & 200 & 200 & 20 & 200 & 25 \\
\hline \multirow[t]{2}{*}{6} & $P(m g / l)$ & April & 3.8 & 0.3 & 2.3 & 0.4 & 0.5 \\
\hline & & July & 3.9 & 2.8 & 2.4 & 0.3 & 2.6 \\
\hline \multirow[t]{2}{*}{7} & BOD (mg/l) & April & 125 & 25 & 15 & 5 & 20 \\
\hline & & July & 200 & 100 & 15 & 10 & 80 \\
\hline \multirow[t]{2}{*}{8} & $\operatorname{COD}(\mathrm{mg} / \mathrm{l})$ & April & 390 & 300 & 40 & & \\
\hline & & July & 400 & 310 & 80 & & \\
\hline \multirow[t]{2}{*}{9} & DO (mg/l) & April & 4 & 8 & 4 & 3 & 6 \\
\hline & & July & 10 & 10 & 5 & 5 & 10 \\
\hline
\end{tabular}



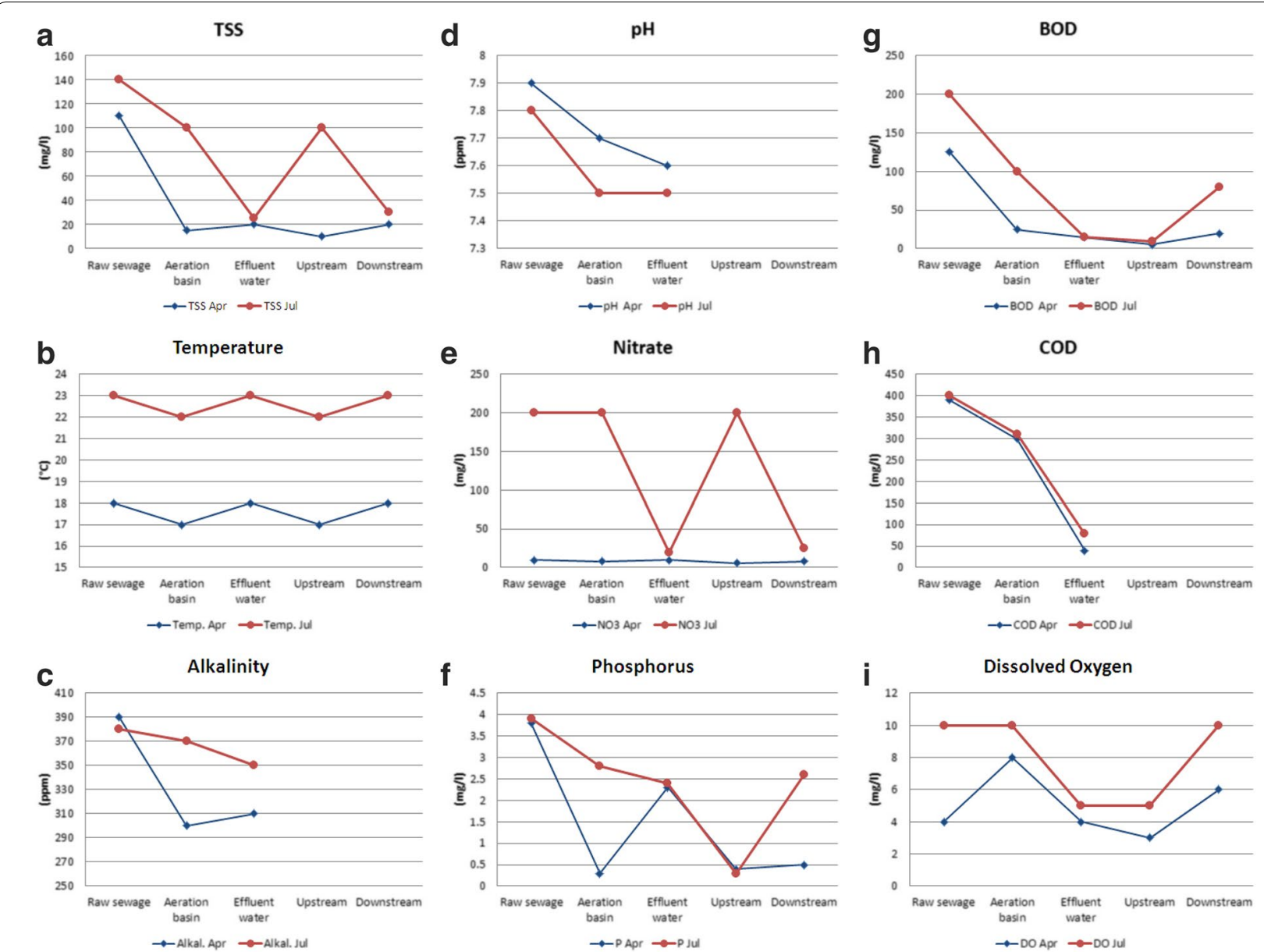

Fig. 3 Plot of temporal and spatial changes of physicochemical variables. a TSS, $\mathbf{b}$ temperature, $\mathbf{c}$ alkalinity, $\mathbf{d}$ pH, e nitrate, $\mathbf{f}$ phosphorus, $\mathbf{g}$ BOD, $\mathbf{h}$ COD, and i DO

Table 3 The removal efficiency of pollutions based on effluent water and raw sewage values

\begin{tabular}{|c|c|c|c|c|c|}
\hline No. & Pollution & Time & Raw sewage & Effluent water & Efficiency (\%) \\
\hline \multirow[t]{2}{*}{1} & TSS (mg/l) & April & 110 & 20 & 81 \\
\hline & & July & 140 & 25 & 82 \\
\hline \multirow[t]{2}{*}{5} & $\mathrm{NO}_{3}(\mathrm{mg} / \mathrm{l})$ & April & 10 & 10 & - \\
\hline & & July & 200 & 20 & 90 \\
\hline \multirow[t]{2}{*}{7} & $\mathrm{BOD}(\mathrm{mg} / \mathrm{l})$ & April & 125 & 15 & 88 \\
\hline & & July & 200 & 15 & 92 \\
\hline \multirow[t]{2}{*}{9} & $\operatorname{COD}(\mathrm{mg} / \mathrm{l})$ & April & 390 & 40 & 89 \\
\hline & & July & 400 & 80 & 80 \\
\hline
\end{tabular}

\section{Water alkalinity}

Alkalinity is a criterion for water ability to neutralize acids. The components of alkalinity in geological systems include $\mathrm{HCO}_{3}{ }^{-}, \mathrm{CO}_{3}{ }^{2-}, \mathrm{OH}^{-}, \mathrm{HSiO}^{3-}, \mathrm{H}_{2} \mathrm{BO}_{3}{ }^{-}$, $\mathrm{HPO}_{4}{ }^{2-}, \mathrm{HS}^{-}, \mathrm{NH}_{3}{ }^{-}$. These components are obtained from minerals decomposition in the soil or atmosphere.
The microbial decomposition of organic matter can produce hydrogen sulfide and ammonia. The most popular elements of alkalinity are bicarbonate, carbonate, and hydroxide. In addition to the mineral origin, these materials can be obtained from carbon dioxide and microbial decomposition of organic matter. Overwhelming algae depends on the $\mathrm{pH}$ values of 9-10. High alkalinity gives a bitter taste. The fundamental concern about the water's alkalinity is the reactions that can occur between specific alkalinity and certain cations.

The critical amounts of alkalinity for drinking water or sewage by the EPO have not yet been determined. The water's alkalinity is mostly due to bicarbonate and carbonate ions presence (usually associated with ions $\mathrm{K}$, $\mathrm{Na}, \mathrm{Mg}, \mathrm{Ca}$ ) and hydroxides in water. The alkalinity is often measured based on the amount of carbonate and bicarbonate in terms of calcium carbonate. The alkalinity of water can be due to the relationship between carbon dioxide alkalinity and $\mathrm{pH}$ below the neutral point $(\mathrm{pH}=7)$. At $\mathrm{pH} 4.6-8.3$, water alkalinity is in the form 


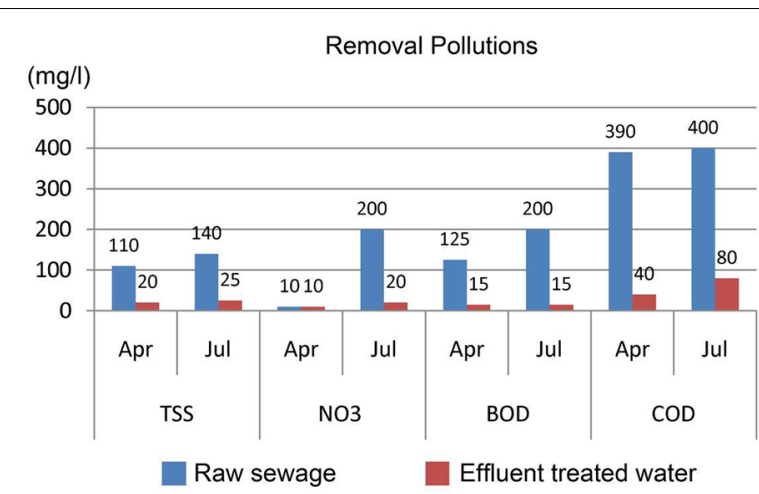

Fig. 4 The removal pollutions of TSS, $\mathrm{NO}_{3}, \mathrm{BOD}$, and $\mathrm{COD}$ compared between effluent water and raw sewage values

of the balance between bicarbonate and carbon dioxide. When the $\mathrm{pH}$ value is higher than 8.3 , free carbon dioxide is terminated, and alkalinity occurs as carbonate and bicarbonate, while $\mathrm{pH} 9.4-10$ is due to the presence of hydroxide in water. When alkalinity is due to carbonate, it also forms a temporary harshness. The alkalinity is one of the factors controlling the processes of sewage treatment. As illustrated data in Table 2 and Fig. 3c, the alkalinity in treated effluent water has been reduced due to the addition of some acids to wastewater in the treatment process. This variable has been overall decreased by treatment process at effluent water $(300-350 \mathrm{mg} / \mathrm{l}) \mathrm{com}$ pared with raw sewage amounts $(380-390 \mathrm{mg} / \mathrm{l})$.

\section{Water acidity $(\mathrm{pH})$}

$\mathrm{pH}$ is a logarithmic measure that determines the amount of acidic being. Two electrical and colorimetric methods can measure the $\mathrm{pH}$. In the electrical method, the hydrogen electrode is used. It is difficult to use the hydrogen electrode, especially if the solution has substances that are absorbed on the platinum electrode. Nowadays, instead of the hydrogen electrode, the glass electrode is used. This electrode measures the potential created by hydrogen ions without interfering with other ions. The colorimetric method, detectors are used. The hydrogen electrode calibrates the detectors to find their specific color at different $\mathrm{pH}$. Therefore, $\mathrm{pH}$ above 7 , alkaline water, and $\mathrm{pH}$ are one of the most important physicochemical properties of water, since they depend more on $\mathrm{pH}$ than water treatment methods. In neutral water, the $\mathrm{H}^{+}$concentration is equal to the $\mathrm{OH}^{-}$one. Natural water $\mathrm{pH}$ is 4-9 and because that the underground layer has alkaline state water becomes alkaline.

Temporal changes in samples acidity at different locations show that the processes of neutralizing wastewater acidity affect the process of slight changes in the $\mathrm{pH}$ reduction in the aeration stage and effluent water compared to the raw sewage (Table 2 and Fig. 3d). In the rainy time of April month, a slight decrease in $\mathrm{pH}$ is observed due to the precipitation effect. According to the environmental standard of EPO, the $\mathrm{pH}$ level in the effluent water to surface water should be ranged between 6.5 and 8.6. Hence, the $\mathrm{pH}$ of all samples is in the range of environmental standards.

\section{Nitrate $\left(\mathrm{NO}_{3}\right)$}

Nitrate is the final product of aerobic stabilization of nitrogenous compounds and is considered as the most stable oxygen-containing compounds suspected in water. In natural water resources, nitrate levels are often low $(<20 \mathrm{mg} / \mathrm{l})$. Discharging a large amount of sewage and wastewater is the most important source of nitrate for surface water higher than groundwater. Measurement of nitrate by spectrophotometer (UV) is used to measure nitrate of samples containing low amounts of organic matter, non-contaminated water samples, and drinking fresh water sources. Measuring the UV absorbance at $220 \mathrm{~nm}$ is possible to find the amount of nitrate quickly, because dissolved organic matter may be absorbed in wavelengths of 275 and $220 \mathrm{~nm}$, and nitrate is only absorbed in $220 \mathrm{~nm}$. Therefore, simultaneous measurement of sample absorption at $275 \mathrm{~nm}$ can help the nitrate absorption in the sample and organic matter removal.

The results of measuring the nitrate content of samples showed that the amount of nitrate within the treatment process is decreased (Table 2 and Fig. 3e). In April month, nitrate values into both raw sewage and effluent water are registered similar to $10 \mathrm{mg} / \mathrm{l}$. In July month, nitrate values in the raw sewage and the effluent water to the river have been registered as 200 and $20 \mathrm{mg} / \mathrm{l}$, respectively indicating acceptable result compared to a threshold of environmental standards $(<50 \mathrm{mg} / \mathrm{l})$. Therefore, the removal efficiency for the $\mathrm{NO}_{3}$ is estimated equal $90 \%$ during the water purification process in KWTP (Table 3 and Fig. 4).

\section{Phosphorus}

Phosphorus is present in most natural waters and wastewater almost exclusively in the form of phosphate. Phosphates exist in three forms of orthophosphates, polyphosphates, or dense phosphates, and organic phosphates in nature, which can be found in solution, in fine and coarse particles, or in aquatic organisms. Different forms of phosphate are produced from a variety of sources. Conventionally, some polyphosphates is added to the process of wastewater purification. Then, phosphates are widely used in boiler water treatment. The orthophosphates called as agricultural fertilizers can be introduced into surface waters when floods or snow 
melting erodes the soil. The aquatic organisms produce these components.

Changes in phosphorus content at different times and locations (Table 2 and Fig. 3f) showed that the value had been overall decreased by treatment process at effluent water (2.3-2.4 mg/l) compared with raw sewage amounts (3.8-3.9 $\mathrm{mg} / \mathrm{l})$. According to the environmental standard of EPO, the phosphorus level in the effluent water to surface water should be ranged below than $6 \mathrm{mg} / \mathrm{l}$. Hence, the phosphorus of all samples is in the range of environmental standards. This result indicates the effectiveness of the wastewater treatment processes and the removal of sludge during the treatment process.

\section{Biological oxygen demand (BOD)}

BOD is the amount of oxygen needed for bacteria to decompose organic matter under aerobic conditions. The amount of BOD can be measured by determining the remaining dissolved oxygen at different times. For the BOD test, the sample should be kept from contact with the air so that the dissolved oxygen content does not change. The oxidation reactions that occur in the BOD test are the result of bacterial activity, temperature, and $\mathrm{pH}$. Usually, the BOD test is carried out at $20^{\circ} \mathrm{C}$. Within 20 days, approximately 95 to $99 \%$ of the organic matter can be oxidized in a treatment process. Besides, a large percentage of organic matter (about $70 \%$ ) are decomposed in the first 5 days, which is called as $\mathrm{BOD}_{5}$. The method of measuring $\mathrm{BOD}$ is based on determining the amount of dissolved oxygen. The BOD unit is expressed in $\mathrm{mg}$ of $\mathrm{O}_{2}$ per liter.

The results of measuring the amount of $\mathrm{BOD}$ in the samples (Table 2 and Fig. 3g) showed the high-efficiency of the wastewater treatment processes and elimination of BOD during the treatment process. The BOD values overall decreased by treatment process at effluent water (15 mg/l) compared with raw sewage amounts (125$200 \mathrm{mg} / \mathrm{l})$. According to the environmental standard of $E P O$, the BOD level in the effluent water to surface water should be ranged below than $30 \mathrm{mg} / \mathrm{l}$. Hence, the BOD value of effluent samples in all samples is in the range of environmental standards. Therefore, the removal efficiency for the BOD is estimated equal $88-92 \%$ during the water purification process in KWTP (Table 3 and Fig. 4).

\section{Chemical oxygen demand (COD)}

COD is the amount of oxygen needed for the chemical oxidation of organic matter in a sample. The COD test is used to measure the amount of organic matter from sewage and natural waters. This test is one of the most common tests to find the severity of domestic and industrial sewage pollution. During the COD test, organic matter, regardless of their origin, turns into carbonic anhydride
$\left(\mathrm{CO}_{2}\right)$ and water, and if nitrogen is present in organic matter, then it is first converted to ammonia and then into nitrate. The COD test is also used to measure an organic matter of industrial and domestic sewage that has toxic compounds for biological life. Generally, the amount of COD in wastewater is more than BOD value.

The results of measuring the amount of the COD in the samples (Table 2 and Fig. 3 h) showed the value had been overall decreased by treatment process at effluent water (40-80 mg/l) compared with raw sewage amounts (390$400 \mathrm{mg} / \mathrm{l})$. According to the environmental standard of $E P O$, the COD level in the effluent water to surface water should be ranged below than $60 \mathrm{mg} / \mathrm{l}$. Hence, the COD value of effluent samples in April month $(40 \mathrm{mg} / \mathrm{l})$ is in the range of environmental standards. Nevertheless, the COD value of effluent samples in July month $(80 \mathrm{mg} / \mathrm{l})$ is over than environmental standards. Comparison of changes in this variable in the wet time (April) and dry time (July) showed that the amount of the COD in dried climate is higher than the humid climate. It seems that the KWTP process in July needs more time to recycle the sewage in aeration and sedimentation basins in order to an effective decrease of COD. In the current situation, the removal efficiency for the COD is estimated at $80-89 \%$ during the water purification process in KWTP (Table 3 and Fig. 4).

\section{Dissolved oxygen (DO)}

All living organisms need oxygen in different forms to carry out metabolism and provide energy for growth and reproduction. Oxygen solubility varies in different water temperature. The amount of solubility of oxygen in pure water is varied from $6 \mathrm{mg} / \mathrm{l}$ at $0{ }^{\circ} \mathrm{C}$ to $7 \mathrm{mg} / \mathrm{l}$ at $35{ }^{\circ} \mathrm{C}$ under one atmospheric pressure. The lack of oxygen solubility in water is one of the main factors that reduce natural water purification and self-cleaning capacity. Increasing soluble oxygen in sewage is a reason for determining aerobic and anaerobic reactions.

According to Table 2 and Fig. 3i, DO content of the samples showed an increased value due to the aeration processes applied in the treatment plant during the stages from aeration basins to effluent water stage. The amounts of DO in the effluent samples $(4-5 \mathrm{mg} / \mathrm{l})$ are slightly over than environmental standard as $2 \mathrm{mg} / \mathrm{l}$. To overcome this environmental problem and decrease dissolved oxygen, establishing of a boiling tank is necessary before the final effluent stage.

\section{Estimation of environmental change}

Based on the Eq. 1, a comprehensive investigation of the environmental changes was carried out to reveal the role of treating the process of KWTP into the aquatic environment of the study area. For this purpose, the estimation 
of environmental change index $\left(\Delta Y_{i}\right)$ and its components were computed in Table 4. Based on the table, the pollution modification ratio $(\Delta X)$ was estimated between 0.08 and 1.00, with an average of 0.24 for all variables TSS, $\mathrm{NO}_{3}, \mathrm{BOD}$, and COD. Consequently, the environmental change index $\left(\Delta Y_{i}\right)$ was estimated between 0.04 and 0.88 , with an average of 0.28 for all variables TSS, $\mathrm{NO}_{3}, \mathrm{BOD}$, and COD at different time intervals. The lowest values of $\Delta Y_{i}$ were obtained for BOD variable equal to 0.04 and 0.08 in July and April months, respectively, indicating the lowest degree of environmental changes and higher efficiency of treating wastewater in KWTP. Likewise, the medium ranges of $\Delta Y_{i}$ were obtained for COD and TSS variables between 0.10 and 0.39 . In vice versa, the highest values of $\Delta Y_{i}$ were obtained for $\mathrm{NO}_{3}$ variable equal to 0.45 and 0.88 in July and April months, respectively. This result indicates that treating process in KWTP for $\mathrm{NO}_{3}$ variable is relatively weak concerning other variables.

\section{Discussion}

The results of measuring the TSS showed its value had been overall decreased by treatment process at effluent water $(20-25 \mathrm{mg} / \mathrm{l})$ compared with raw sewage amounts $(110-140 \mathrm{mg} / \mathrm{l})$. The environmental change index $\left(\Delta Y_{i}\right)$ indicated that the lowest degree of environmental changes in the current status and higher efficiency of treating wastewater in KWTP belongs to TSS variable (0.04-0.08). Measuring the temperature of water samples revealed similar values for treated and natural water temperature at different times $\left(22-23{ }^{\circ} \mathrm{C}\right.$ on July and $17-18{ }^{\circ} \mathrm{C}$ on Apr). Hence, the KWTP has not any effect on the changes of this variable. The alkalinity has been overall decreased by treatment process at effluent water (300-350 mg/l) compared with raw sewage amounts (380-390 $\mathrm{mg} / \mathrm{l}$ ) due to the addition of some acids during the purification process. The variable of $\mathrm{pH}$ has been slightly reduced in the aeration stage and effluent water compared to the raw sewage.

Table 4 The estimation of environmental change index $\left(\Delta Y_{i}\right)$ and its components

\begin{tabular}{llllll}
\hline No. & Pollution & Time & $\boldsymbol{Y}_{\boldsymbol{i}} / \boldsymbol{X}$ & $\boldsymbol{\Delta} \boldsymbol{X}$ & $\boldsymbol{\Delta} \boldsymbol{Y}_{\boldsymbol{i}}$ \\
\hline 1 & $\mathrm{TSS}(\mathrm{mg} / \mathrm{l})$ & April & 0.75 & 0.18 & 0.14 \\
& & July & 2.17 & 0.18 & 0.39 \\
5 & $\mathrm{NO}_{3}(\mathrm{mg} / \mathrm{l})$ & April & 0.88 & 1.00 & 0.88 \\
& & July & 4.50 & 0.10 & 0.45 \\
7 & $\mathrm{BOD}(\mathrm{mg} / \mathrm{l})$ & April & 0.63 & 0.12 & 0.08 \\
& & July & 0.56 & 0.08 & 0.04 \\
9 & $\mathrm{COD}(\mathrm{mg} / \mathrm{l})$ & April & 1.00 & 0.10 & 0.10 \\
& & July & 1.00 & 0.20 & 0.20 \\
Average & & & 1.43 & 0.24 & 0.28 \\
\hline
\end{tabular}

Nitrate values in the raw sewage and the effluent water to the river have been registered as 200 and $20 \mathrm{mg} / \mathrm{l}$, respectively. The environmental change index $\left(\Delta Y_{i}\right)$ indicated that the maximized degree of environmental changes in current status belongs to nitrate variable (0.45-0.88). Changes in phosphorus content showed that the value had been overall decreased by treatment process at effluent water $(2.3-2.4 \mathrm{mg} / \mathrm{l})$ compared with raw sewage amounts $(3.8-3.9 \mathrm{mg} / \mathrm{l})$. The BOD values have been overall decreased by treatment process at effluent water $(15 \mathrm{mg} / \mathrm{l})$ compared with raw sewage amounts (125-200 mg/l). Besides, measuring the amount of the COD revealed that the value had been overall decreased by treatment process at effluent water $(40-80 \mathrm{mg} / \mathrm{l}) \mathrm{com}$ pared with raw sewage amounts $(390-400 \mathrm{mg} / \mathrm{l})$. DO content of the samples showed an increased value due to the aeration processes applied in the treatment plant during the stages from aeration basins to effluent water and downstream points. Meanwhile, the stream water's selfcleaning capacity may contribute to the increasing DO values in downstream (Odjadjare and Okoh 2010).

Several indicators, such as BOD and COD removal efficiencies are used to comparatively analyze a variety of wastewater treatment systems (Colmenarejo et al. 2006). Cumulative BOD and COD efficiency indices that help the determination of the overall efficiency have the main role in average nutrient integrated efficiency (NIE) of the treated effluent water (Mahapatra et al. 2013). Hence, the overall efficiency of treatment plants can be measured based on the chemical parameters of BOD and COD (Carducci and Verani 2013). Overall, the removal efficiency for the BOD and COD was estimated at $80-92 \%$ during the water treating in KWTP.

\section{Conclusion}

The issue of sewage contamination and its effects on environmental tissues is the main part of water resource studies. In this study, to investigate the environmental impacts of Kermanshah wastewater treatment plant (KWTP) on some physicochemical variables of effluent treated waters into Qarasou River, several water samples were collected from different locations into KWTP and along the Qarasou River in different time intervals of April and July 2017.

The results showed that except COD and DO variables; the values of other obtained variables are in standard ranges of the Environmental Protection Organization of Iran for the effluent treated water to streams and surface water. Therefore, the removal efficiency for the TSS, $\mathrm{NO}_{3}, \mathrm{BOD}$, and COD is estimated by $80-92 \%$ during the water purification process in KWTP. Based on previous analysis carried out on the raw and treated sewage in KWTP in 2012, biologic 
pollutants, parasites, and heavy metal comparisons have not been observed, and the efficiency of purification process has been obtained as $80 \%$ (KWWA 2012). Therefore, a survey on KWTP in 2013 estimated the efficiency of the purification process approximately $80 \%$ (Almasi et al. 2013). The results of the present study revealed the similar and progressed status of water efficiency of purification. Hence, it can be mentioned that the activated sludge process of KWTP has not any risky impact on Qarasou River and the whole environment. Similarly, in previous studies focusing on KWTP, several researches have reported the proper disinfection method in removal biologic parasites (Sharafi et al. $2015 \mathrm{a}, \mathrm{b})$ the proper effect of the treatment process for removal pollution nearby to $81 \%$ (Almasi et al. 2016) and the quality of treated water for reuse in agricultural irrigation (Dindarlou and Dastourani 2017).

Application of this result can play an essential role in designing and optimally implementing the next units of the treatment plant in the future. There are some suggestions to enhance the treatment process. First, to overcome the high amounts of dissolved oxygen in the treatment process, establishing of a boiling tank is suggested before the final effluent stage. Second, it seems that the KWTP process in dry months needs more time to recycle the sewage in aeration and sedimentation basins in order to the effective decrease of COD.

\section{Abbreviations \\ APHA: American Public Health Association; BOD: biological oxygen demand; COD: chemical oxygen demand; DO: dissolved oxygen; EPO: Environmental Protection Organization; GSI: geological survey of Iran; KWTP: Kermanshah wastewater treatment plant; KWWA: Kermanshah Water and Wastewater Agency; TSS: total suspended solids.}

\section{Acknowledgements}

We thank anonymous reviewers for technical suggestions on data interpretations.

\section{Informed consent}

Informed consent was obtained from individual participant included in the study.

\section{Authors' contributions}

All authors were equally involved in analyzing and editing the paper. All authors read and approved the final manuscript.

\section{Funding}

This study was not funded by any grant.

\section{Availability of data and materials}

The data that support the findings of this study are available from the corresponding author upon request.

\section{Ethics approval and consent to participate}

This article does not contain any studies with participants performed by any of the authors.

\section{Consent for publication}

Not applicable.

\section{Competing interests}

The authors declare that they have no competing interests.

\section{Author details}

${ }^{1}$ Department of Geology, Basic Science Faculty, Islamic Azad University of Khorramabad, Khorramabad, Iran. ${ }^{2}$ Department of Geography and Natural Hazards, Research Institute of Shakhes Pajouh, Isfahan, Iran.

Received: 21 February 2019 Accepted: 18 May 2019

Published online: 28 May 2019

\section{References}

Almasi A, Sharafi K, Hazrati S, Fazlzadehdavil M (2013) A survey on the ratio of effluent algal BOD concentration in primary and secondary facultative ponds to influent raw BOD concentration. Desalin Water Treat 53(13):3475-3481

Almasi A, Dargahi A, Delangizan S, Hashemian AH, Naderi M (2016) Comparison of the cost-effectiveness of activated sludge systems with natural wastewater treatment systems in Kermanshah Province. Water Wastewater 27(2):44-53 (in Persian)

APHA (1992) Standard methods for the examination of water and wastewater. American Public Health Association, Washington, DC

Boyd B, Greenwood R (2005) Water quality trading: assessment methods and lessons. Environ Qual Manag 14(4):23-29

Burdon FJ, Reyes M, Alder AC, Joss A, Ort C, Räsänen K, Eggen Rl, Stamm C (2016) Environmental context and magnitude of disturbance influence trait-mediated community responses to wastewater in streams. Ecol Evol 6(12):3923-3939

Caixeta CE, Cammarota MC, Xavier AM (2002) Slaughter house wastewater treatment: evaluation of a new three-phase separation system in a UASB reactor. Bioresour Technol 81:61-69

Carducci A, Verani M (2013) Effects of bacterial, chemical, physical and meteorological variables on virus removal by a wastewater treatment plant. Food Environ Virol 5:69-76

Colmenarejo MF, Rubio A, Sanchez E, Vicente J, Gracia MG, Bojra R (2006) Evaluation of municipal wastewater treatment plants with different technologies at Las-Rozas, Madrid (Spain). J Environ Manag 81(4):399-404

Del Pozo R, Diez V (2005) Integrated anaerobic-aerobic fixed-film reactor for slaughterhouse wastewater treatment. Water Res 39:1114-1122

Deng Y, Binghui Z, Goo F, Kun L, Zicheng I (2010) The study on the total water pollutant load allocation in the Changjiang (Yangtze River) Estuary and adjacent seawater area. Estuar Coast Shelf Sci 86:331-336

Dindarlou A, Dastourani M (2017) Investigation of the efficiency of sewage treatment using activated sludge method to supply water for reuse in agricultural irrigation (case study: Kermanshah sewage treatment plant). Water Sustain Dev 4(2):31-40 (in Persian)

EPO (2015) Standards of pollutants in effluent treated waters. Environmental Protection Organization of Iran, Tehran

Essien OE (2010) The effect of anthropogenic pollution loads along Ikpa River tributary under urbanization expansion. J Appl Sci Environ Sanit 5(3):273-282

Farzadkia M, Vanani AF, Golbaz S, Sajadi HS, Bazrafshan E (2016) Characterization and evaluation of treatability of wastewater generated in Khuzestan livestock slaughterhouses and assessing of their wastewater treatment systems. Glob NEST J 18(1):108-118

GSI (2015) Geological sheets at scale 1:100,000. Archived by Geological Survey of Iran. http://www.gsi.ir. Accessed 20 Mar 2015

Hijmans RJ, Cameron SE, Parra JL, Jones PG, Jarvis A (2005) Very high resolution interpolated climate surfaces for global land areas. Int J Climatol 25(15):1965-1978

Hospido A, Moreira MT, Fernández-Couto M, Feijoo G (2004) Environmental performance of a municipal wastewater treatment plant. Int J Life Cycle Assess 9:261

Kobya M, Senturk E, Bayramoglu M (2006) Treatment of poultry slaughterhouse wastewaters by electro coagulation. J Hazard Mater 133:172-176 KWWA (2012) Analysis report of Kermanshah wastewater treatment process. Kermanshah Water and Wastewater Agency, Kermanshah (in Persian) 
Mahapatra DM, Chanakya HN, Ramachandra TV (2013) Treatment efficacy of algae-based sewage treatment plants. Environ Monit Assess 185(9):7145-7164

Manjunath N, Mehrotra I, Mathur R (2000) Treatment of wastewater from slaughterhouse by DAF-UASB system. Water Res 34:1930-1936

Mannino I, Franco D, Piccioni E, Favero L, Mattiuzzo E, Zanetto G (2008) A cost-effectiveness analysis of semi natural wetlands and activated sludge wastewater-treatment systems. Environ Manag 41:118-129

MetcalfE (2003) Wastewater engineering, treatment and reuse. McGraw-Hill, New York

Odjadjare EE, Okoh Al (2010) Physicochemical quality of an urban municipal wastewater effluent and its impact on the receiving environment. Environ Monit Assess 170(1-4):383-394

Sharafi K, Moradi M, Karami Khosravi T (2015a) Comparison of the efficiency of extended aeration activated sludge system and stabilization ponds in real scale in the removal of protozoan cysts and parasite ova from domestic wastewater using Bailenger method: a case study, Kermanshah, Iran. Desalin Water Treat 55:1135-1141

Sharafi K, Fazlzadeh M, Pirsaheb M, Sharafi H, Khosravi T (2015b) Determining parasite presence in raw municipal waste water by Bailenger method in Kermanshah, Iran. Water Qual Expos Health 7(4):525-530
Singh KP, Mohan D, Sinha S, Dalwani R (2004) Impact assessment of treated/ untreated wastewater toxicants discharged by sewage treatment plants on health, agricultural, and environmental quality in the wastewater disposal area. Chemosphere 55:227-255

Tchobanoglus G, Burton FL, Stense HD (2003) Wastewater engineering, 4th edn. McGraw-Hill, Metcalf \& Eddy, New York, pp 1345-1356

Tyagi VK, Kazmi AA, Chopra AK (2008) Removal of fecal indicators and pathogens in a waste stabilization pond system treating municipal wastewater in India. Water Environ Res 80:2111-2117

Zhang R, Qian X, Yuan X, Ye R, Xia B, Wang Y (2012) Simulation of water environmental capacity and pollution load reduction using QUAL2K for water environmental management. Int J Environ Res Public Health 9:4504-4521

\section{Publisher's Note}

Springer Nature remains neutral with regard to jurisdictional claims in published maps and institutional affiliations.

\section{Submit your manuscript to a SpringerOpen ${ }^{\odot}$ journal and benefit from:}

- Convenient online submission

- Rigorous peer review

- Open access: articles freely available online

- High visibility within the field

- Retaining the copyright to your article

Submit your next manuscript at $\boldsymbol{\nabla}$ springeropen.com 